\title{
Alysicarpus ovalifolius (Fabaceae, Desmodieae), a new record for the flora of Brazil
}

\author{
Gustavo Hassemer', João Paulo R. Ferreira² \& Luís A. Funez ${ }^{3}$
}

\begin{abstract}
'Statens Naturhistoriske Museum, Københavns Universitet, Sølvgade 83 S, 1307 Copenhagen, Denmark. gustavonaha@gmail.com
${ }^{2}$ Laboratório de Moluscos Marinhos, Universidade Federal de Santa Catarina, Servidão Beco dos Coroas, 503, 88061-600, Florianópolis, SC, Brazil

${ }_{3}^{3}$ Herbário Dr. Roberto Miguel Klein (FURB), Universidade Regional de Blumenau, Campus I, 89012-900, Blumenau, SC, Brazil
\end{abstract}

Received on 30.IV.2015

Accepted on 21.IX.2017

DOI 10.21826/2446-8231201772302

\begin{abstract}
Alysicarpus ovalifolius (Schumach. \& Thonn.) J. Léonard is a legume species used as forage plant, which is originally native to Africa but today has a pantropical distribution. This species is probably expanding its distribution in the neotropics and therefore can be considered a potentially invasive species. In Brazil, the only species of Alysicarpus Neck. ex Desv. hitherto recorded was A. vaginalis (L.) DC., which is also non-native in the Americas. This study presents the first account of the occurrence and distribution of $A$. ovalifolius in Brazil, including notes on its taxonomic status and potential invasiveness. Brazilian specimens of $A$. ovalifolius had been so far misidentified as $A$. vaginalis. We also present here the first records of the genus Alysicarpus in Santa Catarina state, southern Brazil, and provide an identification key to the two species of Alysicarpus that occur in Brazil.
\end{abstract}

Keywords: Faboideae, ruderal plant, Santa Catarina

RESUMO - Alysicarpus ovalifolius (Fabaceae, Desmodieae), novo registro para a flora do Brasil. Alysicarpus ovalifolius (Schumach. \& Thonn.) J. Léonard é uma leguminosa empregada como forrageira, originária da África, mas que atualmente tem distribuição pantropical. Esta espécie provavelmente está expandindo a sua distribuição nos neotrópicos, e por causa disso pode ser considerada potencialmente invasora. No Brasil, a única espécie de Alysicarpus Neck. ex Desv. registrada até agora é A. vaginalis (L.) DC., que também não é nativa nas Américas. Este estudo apresenta os primeiros registros acerca da ocorrência e distribuição de $A$. ovalifolius no Brasil, incluindo comentários sobre a situação taxonômica desta espécie e seu potencial invasor. Espécimes brasileiros de A. ovalifolius vinham até agora sendo erroneamente identificados como A. vaginalis. Além disso, apresentamos aqui os primeiros registros do gênero Alysicarpus no estado de Santa Catarina, Sul do Brasil, e fornecemos uma chave de identificação para as duas espécies de Alysicarpus que ocorrem no Brasil.

\section{INTRODUCTION}

Alysicarpus Neck. ex Desv. (Fabaceae, subfamily Faboideae) includes ca. 34 species native to the Old World Tropics (Huang \& Huang 1987, Endo \& Ohashi 1990, John \& Thengane 1994, Pedley 2001, Huang \& Ohashi 2010, Torres-Colín et al. 2011), and is most diversified in southern Asia, especially India (Chavan \& Sardesai 2012, Chavan et al. 2013). This genus is part of tribe Desmodieae, which includes $c a$. 26 genera and 520 species (Schrire 1988, Chen \& Huang 1993, Bailey et al. 1997). Species of Fabaceae have an immense ecological, agricultural and economic importance as nitrogen fixers (Soltis et al. 1995, Crews 1999, Mafongoya et al. 2004, Wojciechowski et al. 2004, Tobita et al. 2011).

Despite being native to the Old World tropics, some Alysicarpus species have been introduced and are now naturalised in other tropical and subtropical areas, mainly the neotropics (Sánchez-Blanco et al. 2012) and Australia (Cowie \& Werner 1993). Three Alysicarpus species, $A$. bupleurifolius (L.) DC. (Linné 1753:745-746; Candolle 1825:352-353), A. ovalifolius (Schumach. \& Thonn.) J. Léonard (Schumacher 1827:359-360; Léonard 1954:8892) and A. vaginalis (L.) DC. (Linné 1753:746; Candolle 1825:353), are known to occur in the Americas (Huang \& Ohashi 2010), where they are not native. The introduction of plants of these species is usually intentional, due to their use as forage crops (Gramshaw et al. 1987, John \& Thengane 1994, Tobita et al. 2011), and secondarily also because of their medicinal properties, especially for treating wounds and fractures (Huang \& Ohashi 2010). However, these Alysicarpus species have also raised conservation concerns, as they can be considered potentially invasive species (Cowie \& Werner 1993, Sánchez-Blanco et al. 2012).

The genus Alysicarpus was hitherto represented in Brazil only by $A$. vaginalis, which has been recorded 
in the following states: Bahia, Espírito Santo, Goiás, Mato Grosso, Mato Grosso do Sul, Paraná, Piauí, Rio de Janeiro, São Paulo and Tocantins (Lima 2015). However, we recently (April 2014) discovered populations of $A$. ovalifolius in landfill areas on Santa Catarina Island, Florianópolis municipality, Santa Catarina state (SC), southern Brazil. This has led us to investigate the occurrence and distribution of this species in Brazil. To this end we revised the Alysicarpus collections at ASE, C, EAC, EFC, FLOR, FURB, GB, HBR, HRB, HUEM, HURB, MBM, $\mathrm{RB}, \mathrm{TEPB}$ and UPCB herbaria (acronyms according to Thiers 2016). To identify the new collections and produce a short description for $A$. ovalifolius, we consulted the following taxonomic works: Endo \& Ohashi (1990), Pedley (2001) and Huang \& Ohashi (2010).

\section{RESULTS AND DISCUSSION}

\section{Identification key to the genus Alysicarpus in Brazil}

1. Annual plants. Pods internally eseptate and jointed, releasing all the seeds at once when broken at one of the joints

A. ovalifolius

1. Perennial plants. Pods internally septate and jointed, breaking up into 1 -seeded segments A. vaginalis

Alysicarpus ovalifolius (Schumach. \& Thonn.) J. Léonard, Bull. Jard. Bot. État Bruxelles 24(1):88-92. 1954. $\equiv$ Hedysarum ovalifolium Schumach. \& Thonn., Beskr. Guin. P1.:359-360. 1827. 三Desmodium ovalifolium (Schumach. \& Thonn.) Walp., Repert. Bot. Syst. 1:737. 1842. $\equiv$ Desmodium thonningianum D. Dietr., Syn. Pl. 4:1147. 1847.

Type (designated by Hassemer 2016): "Ada Guineae", 1784, P.E. Isert s.n. (lectotype C 10003960!). See Fig. 2 in Hassemer (2016).

(Figs. 1A-F, 2)

Annual herbs, 10-100 cm tall. Stem erect or prostrate, often woody at the base, strigose or rarely glabrous. Leaflets usually dimorphic, elliptic or oblong in lower part and lanceolate in upper part, $1-10 \times 0.6-3 \mathrm{~cm}$. Inflorescences terminal or leaf-opposed, laxly flowered; bracteoles absent. Pedicel 1-2 mm, with spreading hooked hairs. Calyx glumaceous, scarious, persistent, 4-lobed, with minute spreading hooked hairs and sparsely ciliate straight hairs; lobes not imbricate, subequal, narrowly triangular-ovate, 3-4 mm, ciliate, apex acuminate. Petals orange, pink or reddish purple, subequal with calyx at anthesis. Legume (1-)4-6(-8)-jointed, (0.5-)1.5-2.2 cm × 1.8-2.3 mm, indehiscent, with dense minute hooked hairs, mostly without septa inside and with ridges at joint. Seeds laterally transversely ellipsoid. This description is based on Endo \& Ohashi (1990), Pedley (2001) and Huang \& Ohashi (2010), and also on the Brazilian specimens.
Alysicarpus ovalifolius is originally native to Africa, but now has a pantropical distribution (Pedley 2001, Huang \& Ohashi 2010). Outside its native range, this species is mostly ruderal, occurring in disturbed habitats, with a strong preference for open, well-illuminated areas.

The classification of Alysicarpus has historically been troublesome, which has resulted in varying species concepts and circumscriptions among different authors. For instance, Meeuwen et al. (1961) and Adema (2003) concluded that A. ovalifolius should be a synonym of $A$. vaginalis, based on the considerable morphological similarity between these two species, and also on the morphological variation within each of them. However, based on our morphological examination of herbarium specimens, and on the available taxonomic literature we follow the treatment of Léonard (1954), Schubert (1963), Verdcourt (1971, 1974), Endo \& Ohashi (1990), Pedley (2001) and Huang \& Ohashi (2010) in recognising these two species as distinct. Alysicarpus ovalifolius and $A$. vaginalis have considerable differences in their pods (see identification key above). Most notably, A. ovalifolius has eseptate pods, which when mature rather easily break apart at any of their joints, releasing all seeds at once. Conversely, A. vaginalis has septate pods, which when mature very easily separate into one-seeded segments; each seed is completely enclosed within septa and part of the pericarp. These morphological differences in the pods and seeds make for different dispersal mechanisms for these two species (Endo \& Ohashi 1990). Furthermore, $A$. ovalifolius is native to Africa (Pedley 2001) —we conjecture that it originated in tropical western Africa-whereas $A$. vaginalis is native to tropical eastern Africa and southern Asia; however, both species have a pantropical distribution today.

We noticed that $A$. ovalifolius and $A$. vaginalis are commonly confused with one another among herbarium collections, especially at Brazilian herbaria. Furthermore, many examined specimens were not possible to identify, because they lacked mature fruits. For the reliable identification of specimens of Alysicarpus, it is critically necessary that they include mature fruits. The present study should help towards the correct identification of these two species in the Americas.

Our collections of $A$. ovalifolius from Santa Catarina Island are the first records of the genus Alysicarpus in SC. This is also the second record of a vascular plant new to $\mathrm{SC}$ which has been collected in landfills on Santa Catarina Island (the other is Melilotus albus Medik. (Medikus 1787:382) (Fabaceae), whose populations were discovered in 2011; see Hassemer et al. 2015). We believe that these species have been introduced to the Island when the landfills were created, most probably by seeds carried on the wheels of the construction vehicles. Both $A$. ovalifolius and $M$. albus are additions to the recorded ruderal vascular flora of Santa Catarina Island (Hassemer \& Trevisan 2012). In Brazil, we confirmed the occurrence of $A$. ovalifolius in the following states: Goiás, Mato Grosso, Mato Grosso do Sul, Minas Gerais, Paraná, Rio de Janeiro and SC. However, 
A

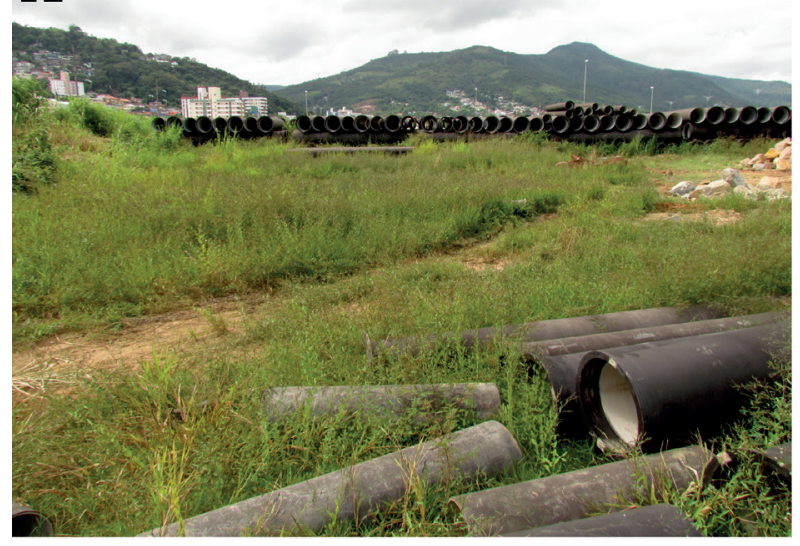

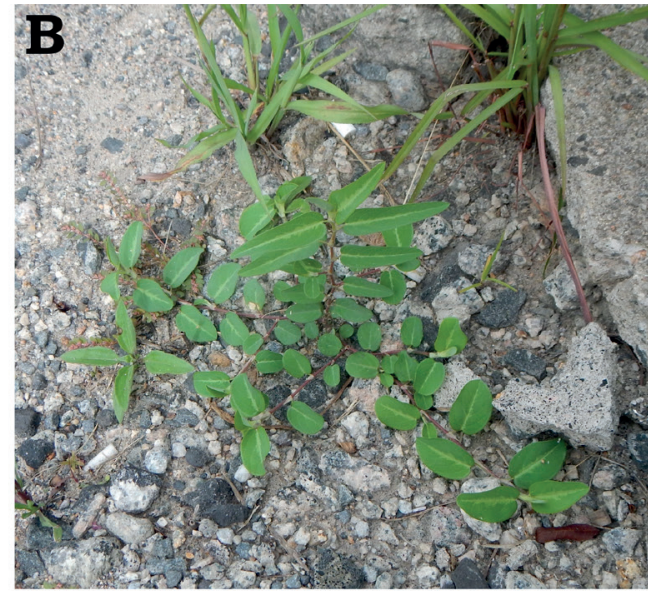

D
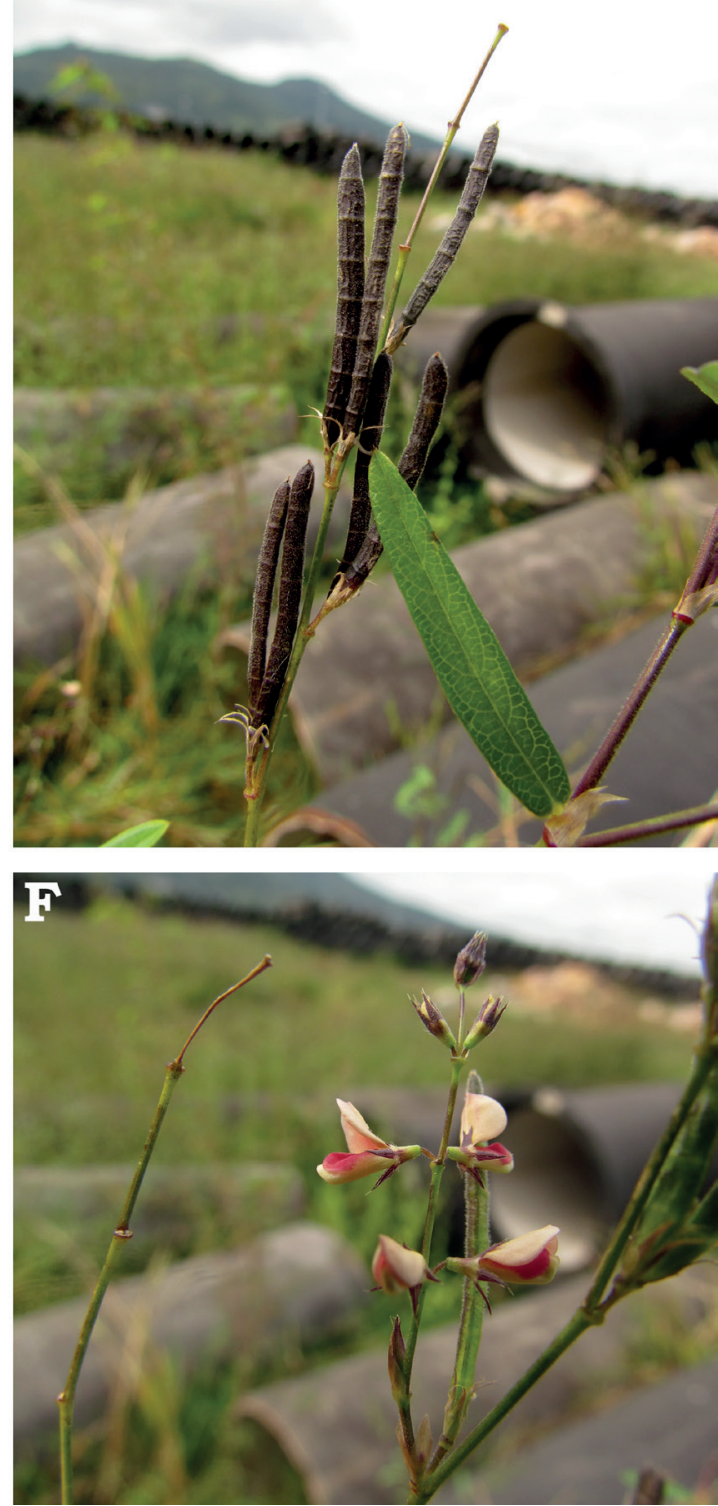

Figs. 1A-F. Alysicarpus ovalifolius from Santa Catarina Island, southern Brazil. A. Overview of the landfill of Saco dos Limões, where the first population of this species in Santa Catarina state was discovered; B. A. ovalifolius growing in cracks by the roadside; C. Adult specimen of $A$. ovalifolius in the landfill of Saco dos Limões; D. Mature pods; E, F. Flowers. Photograph credits Figs. 1A, C-F: L. A. Funez, on 15 April 2015 ; Fig. 1B: G. Hassemer, on 16 February 2015. 


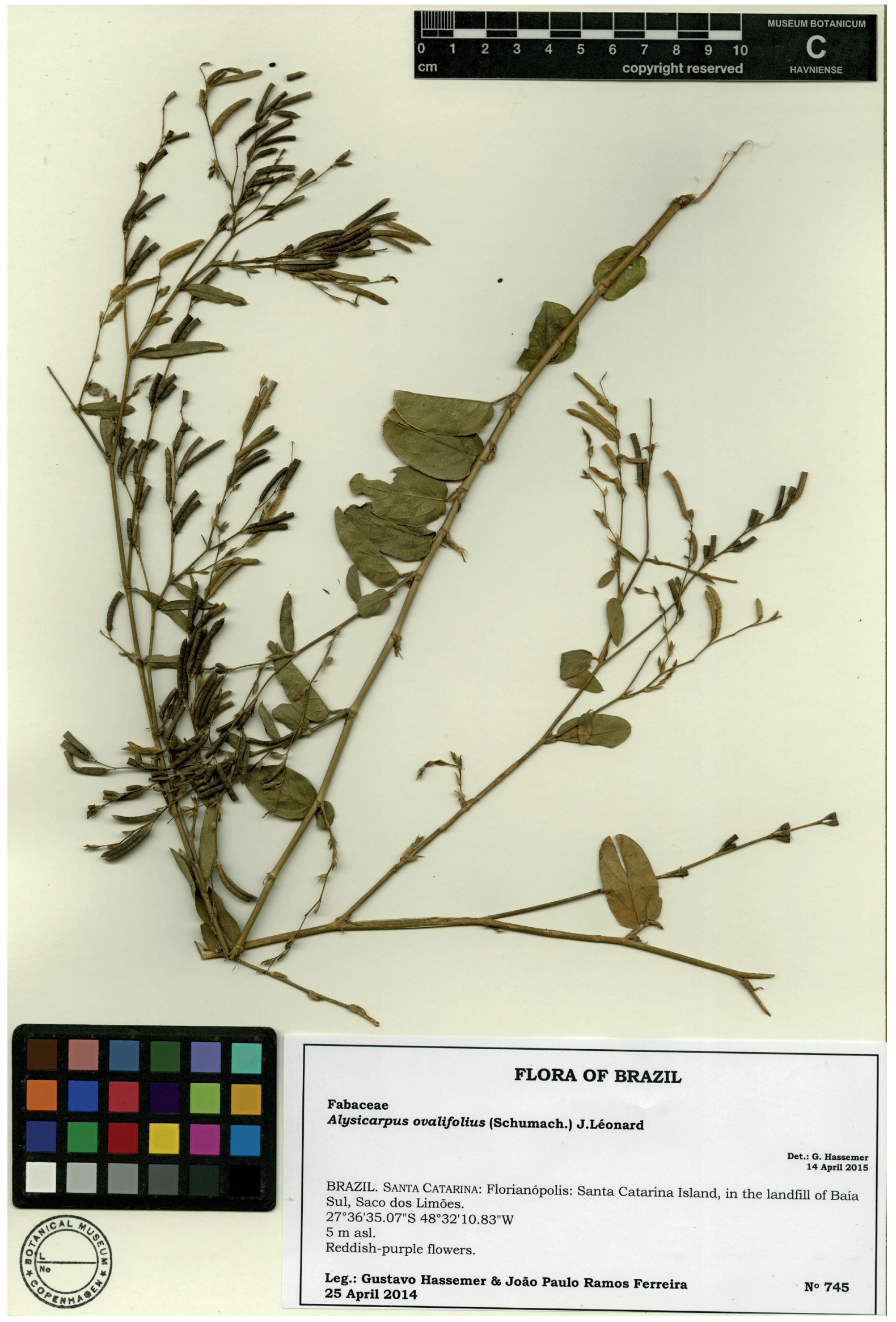

Fig. 2. Herbarium specimen of Alysicarpus ovalifolius (G. Hassemer \& J.P.R. Ferreira 745, C) collected on Santa Catarina Island on 25 April 2014. 
the actual distribution of $A$. ovalifolius in Brazil is most probably much wider than this, and we believe that plants of this species have the potential to reach all Brazilian states, with only the possible exception of Rio Grande do Sul, which at a higher latitude has a more temperate climate. The conservation status of $A$. ovalifolius is least concern (LC) according to the IUCN $(2012,2016)$ criteria.

Because of its use as a forage plant, it is probable that plants of $A$. ovalifolius have been intentionally introduced to Brazil and subsequently escaped from cultivation, began occurring spontaneously and has now become a naturalised species in the region. This species may also be expanding its distribution elsewhere in South America. However, we believe that is unlikely that this species may become invasive based on our field observations and on studies about its distribution and ecology in Mexico (Sánchez-Blanco et al. 2012). We noticed that this species does not seem able to colonise natural (i.e., non-disturbed) environments on Santa Catarina Island. However, plants of non-native species can become more aggressive colonisers with time, as they get acclimated to new environments, consequently threatening local biodiversity and environmental integrity. It is therefore very important from a biological conservation standpoint to continuously monitor the geographical distributions and the ecological dynamics of populations of non-native species such as those discussed here.

Examined material: "Guinea", P. Thonning s.n. (C10003958, C-10003959). “Ada Guineae”, 1784, P.E. Isert s.n. (C-10003960 [lectotype], C-10003961). BRAZIL. GoIÁs: Iporá: GO-060, sentido Iporá-Piranhas, $16^{\circ} 24^{\prime} 44^{\prime \prime}$ S, $51^{\circ} 15^{\prime} 43^{\prime \prime} \mathrm{W}, 12 . \mathrm{I} .2009$, L.C.P. Lima et al. 514 (RB568903); Мato Grosso: Cuiabá: Coxipó da Ponte, 21.I.1989, A. Krapovickas \& C.L. Cristóbal 43075 (C); Vila Bela da Santíssima Trindade: ao longo de estrada vicinal 6 km NW do centro de Vila Bela, 1459'22" S, 5959'2" W, 214 m, 23.III.2014, M.F. Simon et al. 2279 (RB609230); Mato Grosso do SuL: Corumbá: Nhecolândia, Fazenda Pouso Alto, 14.VI.1995, S.M. de Faria \& A. Pott 956 (FLOR); Minas Gerais: São João del-Rei: terreno baldio atrás do posto Texaco, 2009, M. Sobral 14521 (RB560369); pátio da garagem da viação Presidente, 8.III.2012, M. Sobral \& O.C. Carvalho 14812 (RB-560320); PARANÁ: Santa Isabel do Ivaí: Fazenda 5 As, 13.II.2012, M.C. Souza 2564 (HUEM-22235); Uraí: Sítio Santa Gabriela, 4.V.2005, H. Pansard s.n. (RB-560384); RIO DE JANEIRO: Seropédica: UFRRJ, km 47, 27.IV.1979, C.R. Campêlo 786 (FLOR); SANTA CATARINA: Florianópolis: aterro da Baía Sul, no Saco dos Limões, Ilha de Santa Catarina, ruderal, 27³6'35.07” S, 48³2'10.83” W, 5 m, 25.IV.2014, G. Hassemer \& J.P.R. Ferreira 745 (C, FLOR); Costeira do Pirajubaé, aterro da Baía Sul, 27³6'34.9” S, 48³2'11.8”, W, 15.IV.2015, J.P.R. Ferreira \& L.A. Funez 736 (FLOR); Tapera, em aterro sobre Floresta Ombrófila Densa de Terras Baixas, 2741'0.61” S, 48³1'29.42” W, 20.IV.2015, L.A. Funez 4280 (FURB). ETHIOPIA. GoJJAM: on road from Guba-Mankush to Bambudi, 525 m, 24.X.2010, I. Friis et al. 13563 (C); Illubabor: ca. $20 \mathrm{~km}$ south of Gambela, along the road to Abobo, $650 \mathrm{~m}, 30 . X .1996$, I. Friis et al. 7973 (C). GUINEA. BokÉ: Gaoual, 15.IX.1958, J.G. Adam 8940 (C). GUINEA-BISSAU. Mansoa-Uague, 26.XI.1961, J.A. Pereira 1960 (C). MADAGASCAR. Atsimo-Andrefana: near Beza Mahafaly Reserve, E of Betioky, Ambinda stream E of Sakamena, $150 \mathrm{~m}$, 15.I.1989, P.B Phillipson \& S. Rabesihanaka 3182 (C). NIGERIA. Jebba, at the Niger, $35 \mathrm{~m}, 12 . X I I .1927, O$. Hagerup 742 (C). TANZANIA. Dar es Salaam: University College, 20.V.1967, E. Jaasund 2013 (GB); Selous Game Reserve, ca. 2 km NW of Kingupira, 125 m, 22.IV.1975, K. Vollesen 2269 (C); Selous Game Reserve, Muhinje Area, 300 m, 13.I.1978, K. Vollesen 4879 (C). UGANDA. along the Bahr el Jebel, between Nimule and Gondokoro, 4-25. II.1910, E.A. Mearns 2974 (C); Murchison Falls, 660 m, 6.VII.2001, J. Kalema 2670 (C); Ajai Wildlife Reserve, 24.VII.2001, J. Kalema 2343 (C); Ajai Wildlife Reserve, 13.XII.2001, J. Kalema 3373 (C). UNITED STATES OF AMERICA. Alabama: Baldwin: roadside by Ala 225, 0.8 mi. n. jct. US 31 at Spanish Fort, 22.IX.1969, R. Kral 37414 (C); FLORIDA: Alachua: on dirt road E. of US 441, ca. 2 mi. S. of Gainesville, 5.X.1967, W.G. D'Arcy 2169 (C); Lake: along Fla. 470, near Sumter county line, 9.XI.1970, L. Baltzell 2550 (C).

\section{Alysicarpus vaginalis (L.) DC.}

Examined material: BRAZIL. Mato Grosso do Sul: Miranda: rodovia BR-262, 19.V.2002, G.G. Hatschbach et al. 73125 (C, HRB-50919); Pernambuco: Fernando de Noronha: Morro Branco, 9.IV.1999, A.M. Miranda 3231 (RB-516715); Rio DE JANEIro: Armação de Búzios: entre a Ponta do Criminoso e a Praia Brava, Alto da Brava, 21.V.2004, R.D. Ribeiro et al. 238 (FLOR); Rio de Janeiro: Jacarepaguá, laboratório da FEEMA, 28.IV.1987, $J$. Caminote s.n. (RB-287562); São Pedro da Aldeia, Via Lagos, $\mathrm{km} 39,5$, antes do SOS Via Lagos, $22^{\circ} 48.57^{\prime}$ S, $42^{\circ} 17.55^{\prime}$ W, 12.II.2007, H.C. de Lima et al. 6495 (RB-436834). CHINA. Hong Kong: Chung Chi College, 28.IX.1972, S.Y. Hu 12143 (GB). DOMINICAN REPUBLIC. Puerto Plata, 6.IV.1906, C. Raunkicer 1222 (C); La Cumbre, 8.IV.1906, C. Raunkicer 1140 (C); BARAHONA: 1912, M. Fuertes 481 (C). INDIA. JHARKHAND: Ranchi: 2.X.1952, K.A. Dahlstrand s.n. (GB). SURINAME. Paramaribo, Zorg en Hoop, Commewijnestraat, 21.XI.1955, A.M.E. JonkerVerhoef \& F.P. Jonker 20 (C). TAIWAN. 24.VI.1932, T. Tanaka \& Y. Shimada s.n. (GB). TANZANIA. Dar es Salaam: University College, X.1967, A. Jaasund \& E. Jaasund $2198 A$ (GB). THAILAND. ChIANG MAI: Fang: 350 m, 22.II.1958, T. Sørensen et al. 1517 (C).

\section{ACKNOWLEDGEMENTS}

We thank Hanne Espersen (Botanisk Centralbibliotek, Københavns Universitet) for providing literature for this study; the curators of EAC, HRB, HUEM, HURB, RB 
and TEPB herbaria for the loan of specimens; Ana Zannin (FLOR herbarium) and Marta C. V. Farias (ASE herbarium) for supporting this study; and Heidi M. Meudt for a critical read of the text and improving the English. We acknowledge Coordenação de Aperfeiçoamento de Pessoal de Nível Superior (CAPES) for the scholarships granted to the three of us (G. Hassemer: through the Ciência sem Fronteiras programme, process BEX 13765/13-2).

\section{REFERENCES}

Adema, F. 2003. Notes on Malesian Fabaceae (LeguminosaePapilionoideae). 10. The genus Alysicarpus. Blumea 48(1):145-152. http://dx.doi.org/10.3767/000651903×686105

Bailey, C.D., Doyle, J.J., Kajita, T., Nemoto, T. \& Ohashi, H. 1997. The chloroplast $r p l 2$ intron and ORF184 as phylogenetic markers in the legume tribe Desmodieae. Systematic Botany 22(1):133-138.

Candolle, A.P. de. 1825. Leguminosæ. In Prodromus Systematis Naturalis Regni Vegetabilis (A.P. de Candolle, ed.). Treuttel et Würtz, Paris, v. 2, p. 93-524. http://dx.doi.org/10.5962/bhl.title.286

Chavan, S.Y. \& Sardesai, M.M. 2012. Range extension of Alysicarpus naikianus Pokle (Fabaceae) in western India. Journal of Threatened Taxa 4(5):2590-2592.

Chavan, S.Y., Sardesai, M.M. \& Pokle, D.S. 2013. Alysicarpus sanjappae (Leguminosae: Papilionoideae), a new species from the Western Ghats of India. Kew Bulletin 68:183-186. http://dx.doi.org/10.1007/ s12225-012-9425-x

Chen, S.J. \& Huang, T.C. 1993. Pollen morphology of the tribe Desmodieae (Leguminosae) in Taiwan. Taiwania 38:67-89.

Cowie, I.D. \& Werner, P.A. 1993. Alien plant species invasive in Kakadu National Park, tropical northern Australia. Biological Conservation 63(2):127-135. http://dx.doi.org/10.1016/0006-3207(93)90500-z

Crews, T.E. 1999. The presence of nitrogen fixing legumes in terrestrial communities: evolutionary vs ecological considerations. Biogeochemistry 46(1-3):233-246.

Endo, Y. \& Ohashi, H. 1990. New distinctions between Alysicarpus vaginalis and A. ovalifolius (Leguminosae). Natural History Research 1:43-48.

Gramshaw, D., Pengelly, B.C., Muller, F.W., Harding, W.A.T. \& Williams, R.J. 1987. Classification of a collection of the legume Alysicarpus using morphological and preliminary agronomic attributes. Australian Journal of Agricultural Research 38(2):355-372. http://dx.doi. org $/ 10.1071 / \operatorname{ar} 9870355$

Hassemer, G. \& Trevisan, R. 2012. Levantamento florístico de plantas vasculares espontâneas em ambientes antrópicos no campus da Universidade Federal de Santa Catarina, Florianópolis, Brasil. Biotemas 25(3):75-96. http://dx.doi.org/10.5007/2175$7925.2012 \mathrm{v} 25 \mathrm{n} 3 \mathrm{p} 75$

Hassemer, G., Ferreira, J.P.R., Funez, L.A. \& Trevisan, R. 2015. First records of Melilotus albus Medik. (Fabaceae, Faboideae) in Santa Catarina, southern Brazil. Check List 11(1):e1499. http://dx.doi. org $/ 10.15560 / 11.1 .1499$

Hassemer, G. 2016. Revision of the typification of the name Hedysarum ovalifolium (Fabaceae). Webbia 71(2):233-237. http://dx.doi.org/10 $.1080 / 00837792.2016 .1205210$

Huang, P. \& Ohashi, H. 2010. Alysicarpus Necker ex Desvaux. In Flora of China (Z. Wu, P.H. Raven \& D. Hong, eds.). Science Press, Beijing, and Missouri Botanical Garden, St. Louis, v. 10, p. 290-292.

Huang, S.F. \& Huang, T.C. 1987. Taxonomic treatment of the Papilionoideae (Leguminosae) of Taiwan. Taiwania 32:11-118.

International Union for Conservation of Nature. 2012. IUCN Red List Categories and Criteria. Version 3.1, $2^{\text {nd }}$ ed. IUCN, Gland, 32 p.

International Union for Conservation of Nature. 2016. Guidelines for Using the IUCN Red List Categories and Criteria. Version 12. IUCN, Gland, $101 \mathrm{p}$.
John, C.K. \& Thengane, R.J. 1994. Relationship between nuclear DNA content and speciation in Alysicarpus. Caryologia 47(2):167-177. http://dx.doi.org/10.1080/00087114.1994.10797294

Léonard, J. 1954. Notulae systematicae XV: Papilionaceae-Hedysareae africanae (Aeschynomene, Alysicarpus, Ormocarpum). Bulletin du Jardin Botanique de l'État a Bruxelles 24(1):63-106.

Lima, H.C. de. 2015. Alysicarpus. In Lista de Espécies da Flora do Brasil. Jardim Botânico do Rio de Janeiro. Available at: http://floradobrasil. jbrj.gov.br/jabot/floradobrasil/fb120429. Accessed on 12 July, 2016.

Linné, C. von. 1753. Species Plantarum. L. Salvius, Stockholm, v. 2, p. 561-1200. http://dx.doi.org/10.5962/bhl.title.669

Mafongoya, P.L., Giller, K.E., Odee, D., Gathumbi, S., Ndufa, S.K. \& Sitompul, S.M. 2004. Benefiting from N2-fixation and managing rhizobia. In Below-ground Interactions in Tropical Agroecosystems: Concepts and Models with Multiple Plant Components (M. van Noordwijk, G. Cadisch \& C.K. Ong, eds.). CABI, Wallingford, p. 227-242. http://dx.doi.org/10.1079/9780851996738.0000

Medikus, F.K. 1787. Versuch einer neuen Lehrart, die Pflanzen nach zwei Methoden zugleich, nehmlich nach der künstlichen und natürlichen, zu ordnen, durch ein Beispiel einer natürlichen Familie erörtert. Vorlesungen der Churpfälzischen physikalisch-ökonomischen Gesellschaft 2:327-460.

Meeuwen, M.S. van, Steenis, C.G.G.J. van \& Stemmerik, J. 1961. Preliminary revisions of some genera of Malaysian Papilionaceae II. Reinwardtia 6(1):85-108.

Pedley, L. 2001. Alysicarpus (Leguminosae: Desmodieae) in Australia: a taxonomic revision. Austrobaileya 6(1):107-116.

Sánchez-Blanco, J., Sánchez-Blanco, C., Sousa S., M. \& EspinosaGarcía, F.J. 2012. Assessing introduced Leguminosae in Mexico to identify potentially high-impact invasive species. Acta Botanica Mexicana 100:41-77.

Schrire, B.D. 1988. A synopsis of the tribe Desmodieae (Fabaceae) in southern Africa. Bothalia 18(1):11-24.

Schubert, B.G. 1963. Desmodium: preliminary studies - IV. Journal of the Arnold Arboretum 44:284-297.

Schumacher, H.C.F. 1827. Beskrivelse af guineiske Planter som ere fundne af danske Botanikere, især af Etatsraad Thonning. H. F. Popp, Copenhagen, 466 p. http://dx.doi.org/10.5962/bhl.title.51454

Soltis, D.E., Soltis, P.S., Morgan, D.R., Swensen, S.M., Mullin, B.C., Dowd, J.M. \& Martin, P.G. 1995. Chloroplast gene sequence data suggest a single origin of the predisposition for symbiotic nitrogen fixation in angiosperms. Proceedings of the National Academy of Sciences 92(7):2647-2651. http://dx.doi.org/10.1073/pnas.92.7.2647

Thiers, B. 2016. Index Herbariorum: a global directory of public herbaria and associated staff. New York Botanical Garden's Virtual Herbarium. Available at: http://sweetgum.nybg.org/science/ih. Accessed on 12 July, 2016.

Tobita, S., Shinjo, H., Hayashi, K., Matsunaga, R., Miura, R., Tanaka, U., Abdoulaye, T. \& Ito, O. 2011. Identification of plant genetic resources with high potential contribution to soil fertility enhancement in the Sahel, with special interest in fallow vegetation. In Innovations as Key to the Green Revolution in Africa (A. Bationo, B. Waswa, J.M. Okeyo, F. Maina \& J.M. Kihara, eds.). Springer Science, Dordrecht, p. 701-706. http://dx.doi.org/10.1007/978-90-481-2543-2

Torres-Colín, L., Duno-de-Stefano, R. \& Gómez-Hinostrosa, C. 2011. Los géneros Alysicarpus y Desmodium (Fabaceae) en la península de Yucatán, México. Revista Mexicana de Biodiversidad 82:1087-1097.

Verdcourt, B. 1971. Alysicarpus. In Flora of Tropical East Africa (E. Milne-Redhead \& R.M. Polhill, eds.). Crown Agents for Oversea Governments and Administrations, London, p. 491-501.

Verdcourt, B. 1974. Summary of the Leguminosae-PapilionoideaeHedysareae (sensu lato) of Flora Zambesiaca. Kirkia 9:359-556.

Wojciechowski, M.F., Lavin, M. \& Sanderson, M.J. 2004. A phylogeny of legumes (Leguminosae) based on analysis of the plastid matK gene resolves many well-supported subclades within the family. American Journal of Botany 91(11):1846-1862. http://dx.doi.org/10.3732/ ajb.91.11.1846 